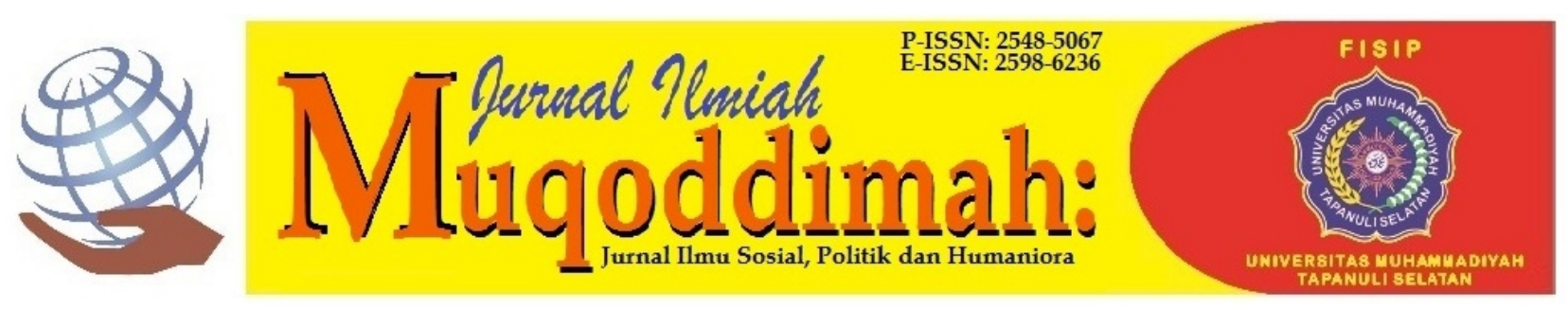

\title{
Mengawal Pemilihan Legilatif Tahun 2019 Di Kota Baubau
}

\author{
L.M. Azhar Sa'ban 1), Nastia ${ }^{2)}$, Andy Arya Maulana Wijaya ${ }^{3)}$, Herman Lawelai ${ }^{4)}$ \\ Program Studi IImu Pemerintahan, Universitas Muhammadiyah Buton \\ Jln. Betoambari No. 36 Kota Bau-Bau, Sulawesi Tenggara \\ izharrazi@gmail.com ${ }^{1)}$ \\ nastiatia567@gmail.com ${ }^{2)}$ \\ bulawambona.87@gmail.com ${ }^{3)}$ \\ hermanlawelai@yahoo.com ${ }^{4}$ )
}

\begin{abstract}
Abstrak
Peranan aktif dari Badan Pengawas Pemilihan UmumKota Baubau sebagai lembaga pemantau dalam mengawasi jalannya pemilihan umum, keberadaan Badan Pengawas Pemilihan Umum Kota Baubau sebagai lembaga pengawas pemilihan umum di Kota Baubau, merupakan hal penting dalam menentukan keberhasilan pelaksanaan pemilihan umum di Kota Baubau yang jujur dan aman. Metode yang digunakan dalam penelitian ini menggunakan metode kualitatif. Teknik pengumpulan datanya dilakukan dengan cara memanfaatkan kepustakaan dan penelusuran data online. Hasil penelitian yang diperoleh adalah kewenangan yang dimiliki oleh Badan Pengawas Pemilihan Umum Kota Baubau, ketegasan dalam melakukan penindakan terhadap pihak-pihak yang melakukan pelanggaran, dalam menyelesaikan pelanggaran-pelanggaran yang terjadi selama pemilihan umum, Badan Pengawas Pemilihan Umum Kota Baubau telah melaksanakan tugas sesuai dengan amanat Undang-Undang yang berlaku.
\end{abstract}

Kata Kunci :Pemilihan Umum Legislatif, Pengawasan

\begin{abstract}
The active role of the Baubau City Election Supervisory Body as a monitoring agency in overseeing the course of general elections, the existence of the Baubau City Election Supervisory Body as the general election supervisory agency in Baubau City, is important in determining the success of the implementation of an honest and safe general election in Baubau City. The method used in this research uses qualitative methods. The data collection technique is done by utilizing literature and online data search. The results of the research obtained are the authority possessed by the General Election Supervisory Agency of the City of Baubau, the firmness in taking action against parties who commit violations, in resolving violations that occur during general elections, the General Election Supervisory Body of the City of Baubau has carried out its duties in accordance with mandate of the applicable law.
\end{abstract}

Keywords: Legislative General Election, Supervision

\section{PENDAHULUAN}

Demokrasi mensyaratkan adanya suksesi kepemimpinanmelalui pemilu secara reguler, selainitu pemilu juga menjadi sarana untukmewujudkan kedaulatan rakyatdengan memilih anggota legislatif (Kartini, 2017).Sekalipun bukan satu-satunya aspek dalam demokrasi, namun Pemilu merupakan satu bagian yang sangat penting, karena Pemilu berperan sebagai mekanisme perubahan politik mengenai pola dan arah 
kebijakan publik dan/atau mengenai sirkulasi elit secara periodik dan tertib (Surbakti, Ramlan; Supriyanto, Didik; Santoso, 2008)

Penyelenggara pemilu menurut Undang-Undang No 7 Tahun 2017 tentang Pemilihan Umum Pasal 1 adalah lembaga yang menyelenggarakan Pemilu yang terdiri atas Komisi Pemilihan Umum, Badan Pengawas Pemilu, dan Dewan Kehormatan Penyelenggaraan Pemilu sebagai satu kesatuan fungsi Penyelenggara Pemilu untuk memilih anggota Dewan Perwakilan Rakyat, anggota Dewan Perwakilan Daerah, Presiden dan Wakil Presiden, dan untuk memilih anggota Dewan Perwakilan Rakyat Daerah secara langsung oleh rakyat.Begitu yang terjadi di Indonesia, pelaksanaan pemilu merupakan sebuah wujud dari demokrasi yang merupakan sarana dalam menentukan aspirasi yang ada pada masyarakat.Tetunya dalam menentukan aspirasi masyarakat tidak terlepas peran partai politik.Dengan memandang pemilu merupakan kesempatan bagi rakyatuntuk memilih pejabat politik, makadiperlukan pengawasan untukmemastikan jalanya pemilu secarajujur dan adil (Kartini, 2017).

Sistem pemilihan langsung ini merupakan bentuk dari perwujudan demokrasi di Indonesia, dimana masyarakat dilibatkan langsung dalam pemilihan umum. Masyarakat yang sudah memenuhi syarat dapat berhak memberikan suaranya unutuk pemilihan Kepala Negara/Presiden, DPR, DPD, DPRD Provinsi dan Kabupaten/Kota melalui pencoblosan di TPS. Tradisi berpikir bebas atau kebebasan berpikir itu pada gilirannya mempengaruhi tumbuh kembangnya prinsip kemerdekaan berserikat dan berorganisasi serta berhak memberikan suaranya (Febriadi, 2018).

Ciri mendasar negara demokrasi adalah keberadaan pemilihan umum (Pemilu). Demokrasi merupakan sistem politik yang memberikan ruang bagi keadilan dan persamaan bagi semua warga negara (Ratnia Solihah, Arry Bainus dan Iding Rosyidin, 2018). Sebagaimana spirit dari demokrasi, sepatutnya rakyat mempunyai peluang yang lebih besaruntuk berkontribusi dalam prosespolitik(Studi et al., 2020).Indonesia yang sedang membangun peradaban politik yang sehat, pelaksanaan pemilu tanpa hadirnya pengawasan secara struktural dan fungsional yang kokoh berpotensi besar akan menimbulkan hilangnya hak pilih warga negara, maraknya politik uang, kampanye hitam, dan pemilu yang tidak sesuai aturan.

Kondisi demokrasi Indonesia saat ini sudah semakin membaik, indikatornya adalah dilaksanakannya pemilihan umum secara kontinyu, bersih dan aman. Tahun 2018 dan 2019 dikatakan sebagai tahun politik di mana pada tahun 2018 dilaksanakan pemilukada secara serentak bersamaan (Anggoro \& Mulyatin, 2020). Pada tahun 2019 pemilu serentak pertama kalinya di selenggarakan di Negara Repoblik Indonesi, ini menjadi sejarah baruh untuk Negara Indonesia, dikarenakan pemilih harus melakukan pemilihan pada lima surat suara yaitu untuk Pemilihan Presiden, Pemilihan Dewan Perwakilan Rakyat Repoblik Indonesia, Dewan Perwakilan Rakyat Daerah Provinsi, Dewan Perwakilan Rakyat Daerah Kabupaten/Kota, dan Dewan Perwakilan Daerah. Kota Baubau adalah salah satu daerah yang mengikuti pemilu serentak tahun 2019. Pemilihan umum legislatif berdasarkan proses pendaftaran calon yang dilaksanakan sesuai dengan tahapan, Komisi Pemilihan Umum Kota Baubau menetapkan sebanyak 320 calon legislatif yang diikuti oleh 16 partai politik yang mengikuti kompetisi.

Terbentang ke depan tantangan akan eksistensi dan peran strategis bagi Bawaslu berdasarkan UU No 7 Tahun 2017 sehingga memiliki kewenangan besar, tidak hanya 
sebagai pengawas, sekaligus sebagai eksekutor dan pemutus perkara untuk membuktikan peran dan eksistensinya mengawal pemilu yang berintegritas bagi kemajuan bangsa.Keberhasilan atau kegagalan pemilu sesungguhnya ditentukan oleh banyak faktor dan aktor.Oleh karena itu, Bawaslu harus mampu menjadi aktor yang menyinergikan seluruh potensi dalam mewujudkan pemilu yang demokratis dan bermartabat. Proses penyelenggaraannya, khususnya dalam pengawasan, harus melibatkan seluruh elemen, baik unsur masyarakat maupun pemangku kepentingan. Proses itu dilaksanakan secara transparan, akuntabel, kredibel, dan partisipatif, agar semua tahapan dapat berjalan baik sesuai koridor aturan yang berlaku.

Dalam menjalankan tugas, kewajibannya dan wewenang mengawasi setiap tahapan pemilu, apa yang dilakukan Bawaslu sebetulnya tidak jauh berbeda dengan apa yang dilakukan pemantau pemilu atau pengamat pemilu, yakni sama-sama mengkritik, menghimbau, dan memproses apabila terdapat hal yang menyimpang dari undang-undang. Namun terkait dengan penanganan kasus-kasus dugaan pelanggaran pemilu, maka disini terdapat perbedaan yang fundamental, karena pengawas pemilu menjadi satu-satunya lembaga yang berhak menerima laporan, dengan kata lain Bawaslu merupakan satu-satunya pintu masuk untuk penyampaian laporan pelanggaran pemilu.

Berdasarkan keputusan KPU RI nomor.291/PL.01.3-Kpt/06/KPU/IV/2018 menetapkan Kota Baubau terbagi atas tiga daerah pemilihan (Dapil) dengan alokasi berjumlah 25 kursi.Berdasarkan keputusan KPU RI tiga dapil di Kota Baubau itu yakni dapil satu meliputi tiga kecamatan masing-masing Kecamatan Batupoaro dengan jumlah penduduk 29.846 jiwa, Kecamatan Betoambari 17.939 jiwa dan Kecamatan Murhum 21.113 jiwa dengan alokasi 11 kursi. Kemudian untuk dapil dua meliputi Kecamatan Wolio dengan jumlah penduduk sebanyak 40.042 jiwa dengan alokasi 7 kursi.Sementara untuk dapil tiga, meliputi Kecamatan Bungi dengan jumlah penduduk sebanyak 7.991 jiwa, Kecamatan Kokalukuna 20.767 jiwa, Kecamatan Lea-Lea 8.734 jiwa dan Kecamatan Sora Wolio 8.055 jiwa dengan alokasi seluruhnya 7 kursi (Antaranews Sultra).

Badan Pengawas Pemilu (Bawaslu) setidaknya telah mencatat 10 perkara yang terjadi selama tahapan Pemilu 2019 berlangsung di Kota Baubau.Satu diantaranya merupakan laporan dari masyarakat dan sembilan lainnya adalah hasil temuan Panwas.Hal itu disampaikan langsung oleh Ketua Bawaslu Kota.la merincikan perkara yang ditanganinya yaitu tiga pelanggaran pidana, lima pelanggaran administrasi dan dua perkara pelanggaran hukum lainnya terkait netralitas Aparatur Sipil Negara (ASN) (Kumparan.com).

Badan Pengawas Pemilu (Bawaslu) Kota Baubau, Sulawesi Tenggara (Sultra) mengusulkan 13 dari 14 Tempat Pemungutan Suara (TPS) untuk dilakukan Pemungutan Suara Ulang (PSU) menyusul dugaan terjadi sejumlah pelanggaran pada proses pemungutan suara pada 17 april lalu. Ketua Bawaslu Baubau, mengatakan kurangnya 1 TPS itu karena KPU Kota Baubau telah melakukan klarifikasi dan perbaikan terkait temuan Bawaslu, sementara 13 TPS lainnya tetap dilakukan PSU karena pemilih yang tidak ber KTP Kota Baubau melakukan pencoblosan di TPS-TPS tersebut (Antaranews.com). 
Peluang adanya pemilu serentak bagi penyelenggara pemilu adalah efisiensi biaya pemilu itu sendiri.Dalam konteks Indonesia, penyelenggara pemilu meliputi KPU dan Bawaslu yang dalam pelaksanaan tugasnya secara etis dikontrol oleh Dewan Kehormatan Penyelenggara Pemilu (DKPP).KPU bertanggung jawab atas penyelenggaraan pemilu mulai dari pendataan pemilih, menerima dan memvalidasi nominasi kontestan pemilu baik partai politik maupun kandidat, melaksanakan pemilu, perhitungan suara dan rekapitulasi suara.Sementara Bawaslu bertugas mengawasi pelaksanaan pemilu agar sesuai dengan asas pemilu yang langsung, umum, bebas, rahasia, jujur dan adil.Dalam pelaksanaan peran dan fungsi tersebut tentunya terkait banyak aspek teknis pemilu dan manajemen pemilu yang harus dilakukan.Sistem pemilu yang berbeda membutuhkan pengaturan dan persiapan serta manajemen pemilu yang berbeda. Peluang terbesar dari penyelenggara pemilu dengan dilaksanakannya pemilu serentak adalah efisiensi anggaran pemilu, karena pemilu tidak lagi dilaksanakan berkali kali.(Solihah, 2018).Berdasarkan apa yang dikemukakan diatas, penulis tertarik untuk mengkajilmplementasi Badan Pengawas Pemilihan Umum Dalam Mengawal Pemilihan Legilatif Tahun 2019 di Kota Baubau, dengan membahas persoalan yang muncul dalam konteks pengawasan, mengidentifikasi pengawasan yang sudah dilakukan selama ini oleh Badan Pengawasan Pemilu Kota Baubau serta upaya yang dilakukan dalam pengawasan untuk mengawal pemilu yang sesuai dengan peraturan perundang-undangan yang berlaku.

\section{METODE}

Kajian ini merupakan penelitian kepustakaan (library research), dengan menggunakan pendekatan deskriptif dan metode kualitatif (Creswell, 2010). Teknik pengumpulan datanya dilakukan dengan cara memanfaatkan kepustakaan dan penelusuran data online.

Data penelitian kemudian dianalisis dengan teknik analisis data kualitatif, yang tahapannya terdiri dari reduksi data atau data reduction; penyajian data atau data display; dan penarikan kesimpulan atau conclusion drawing (Bloor, 1997).

\section{HASIL DAN PEMBAHASAN \\ Gambaran Umum Pemilu Legislatif di Kota Baubau}

Pelaksanaan pemilu merupakan amanah berdasarkan UUD 1945 Bab 1 Pasal 1 ayat 2 yang berbunyi kedaulatan berada ditangan rakyat dan dilakukan menurut Undang-Undang Dasar. Dengan demikian pemilu merupakan salah satu perwujudan jaminan hak asasi warga negara.Setiap warga negara diberikan kebebasan untuk turut serta dalam menentukan kebijakan pemerintah dan salah satunya adalah melalui pemilu yang sering disebut sebagai pesta demokrasi bagi rakyat.Dalam demokrasi moderen yang menjalankan kedaulatan itu adalah wakil-wakil rakyat yang ditentukan sendiri oleh rakyat.Untuk menentukan siapakah yang berwenang mewakili rakyat maka dilaksanakanlah pemilihan umum. Pemilihan umum adalah suatu cara untuk memilih wakil-wakil rakyat yang akan duduk di lembaga perwakilan rakyat serta salah satu pelayanan hak-hak asasi warga negara dalam bidang politik (Syarbaini ddk, 2002). Jadi menurut definisi adalah proses formal pengambilan keputusan kelompok dimana 
anggota masyrakat yang memenuhi persyaratan memilih seseorang untuk memegang jabatan administrasi.

Jumlah partai politik peserta pemilihan umum 2019 di kota Baubau diikuti 16 partai politik Nasional yang merupakan partai besar yakni Partai Golongan Karya (Partai Golkar), Partai Demokrat, Partai Demokrasi Indonesia Perjuangan (PDI-P), Partai Keadilan Sejahtera (PKS), Partai Persatuan Indonesia (Perindo), Partai Persatuan Pembangunan (PPP), Partai Solidaritas Indonesia (PSI), Partai Amanat Nasional (PAN), Patai Berkarya, Partai Bulan Bintang (PBB), Partai Hati Nurani Rakyat (Hanura), Partai Gerakan Indonesia Raya (Gerindra), Partai Keadilan Dan Persatuan Indonesia (PKPI), Partai Kebangkitan Bangsa (PKB), Partai Gerakan Perubahan Indonesia (Partai Garuda), Partai Nasdem. Berdasarkan keputusan Komisi Pemilihan Umum Republik Indonesia (KPU RI) menetapkan kota Baubau terbagi atas tiga dapil dengan alokasi kursi berjumlah 25 kursi.

\section{Implementasi Pelaksanaan Pemilu Legislatif Di Kota Baubau}

Bawaswalu Kota Baubau merupakan satu-satunya lembaga yang bertugas melaksanakan pengawasan dan penindakan terhadap setiap pelanggaran selama tahapan penyelenggaraan pemilihan legislatif.

Keberadaan Bawaslu Kota BauBau merupakan hal penting dalam menentukan keberhasilan pelaksanaan pemilu legislatif agar sesuai dengan ketentuan yang diatur dalam peraturan perundang-undangan.

Salah satu aspek penting dalam mensukseskan pemilu legislatif adalah pengawasan dan penanganan pelanggaran secara maksimal guna menjadikan pemilihan tersebut menjadi pemilihan yang bersih dan sesuai dengan ketentuan Undang-Undang yang berlaku

Untuk mencipatakan pemilu yang bersih, diperlukan pengawasan yang efektif. Efektivitas pengawasan ditentukan oleh para pengawas dalam memahami dan mengerti proses pengawasan dan penanganan pelanggaran itu dijalankan dengan baik. Dalam hal ini, Bawaslu Kota Baubau hadir sebagai lembaga yang ditugaskan oleh UndangUndang dalam mewujudkan pemilihan legislatif yang jujur dan bersih.Pemilu legislatif di Kota Baubau telah berakhir, penetapan perolehan kursi, dan penetapan calon terpilih dalam pemilihan umum, keputusan Komisi Pemilihan Umum Kota Baubau Nomor 188/PL.01.9-Kpt/7472/Kota/VIII/2019 tentang penetapan perolehan kursi partai politik peserta pemilihan umum Anggota Dewan Perwakilan Rakyat Daerah Kota Baubau Pemilhan Umum tahun 2019, dan keputusan Komisi Pemilihan Umum Kota Baubau Nomor 189/PL.01.9-Kpt/7472/Kota/VIII/2019 tentang penetapan calon terpilih Anggota Dewan Perwakilan Rakyat Daerah Kota Baubau Pemilhan Umum tahun 2019 dengan ini KPU Kota Baubau mengumumkan hasil penetapan perolehan kursi dan calon terpilih Anggota Dewan Perwakilan Rakyat Daerah Kota Baubau periode 2019-2024 pemilihan tahun 2019, dapat dilihat pada tabel berikut: 
Tabel 1.

Daftar Calon Terpilih Anggota Dewan Perwakilan Rakyat Daerah Kota Baubau Tahun 2019

\begin{tabular}{clcc}
\hline Dapil & \multicolumn{1}{c}{ Nama Calon Terpilih } & Partai Politik & Suara Sah \\
\hline I & H. Zahari, SE & Golkar & 1.344 \\
& H. Kamil Adi Karim, SP & PAN & 1.643 \\
& Drs. Nasiru & Gerindra & 901 \\
Asaad Adi Karim & PDIP & 1.588 \\
& Siti Suhura, S.Ag., M.Pd & PPP & 705 \\
& Noor Gemilang Siradja, S.IP & Hanura & 707 \\
La Madi & Berkarya & 1.300 \\
Muhammad Ahadayat & Nasdem & 855 \\
Zamani.ST.,MT & PKS & 550 \\
La Ode Abdul Tamin. SH & Golkar & 1.248 \\
Ardin Jufri, ST & PKB & 616 \\
Feto Daud, SE., M.Si & & \\
\hline II & Pa Ode Sahrun & PAN & 1.046 \\
& Hj. Roslina Rahim & Perindo & 1.466 \\
H. Rusdin, S.IP & Golkar & 820 \\
Nur Aksa & PDIP & 727 \\
Acep Sulfan & Gerindra & 819 \\
Haryono Hafied & PKB & 832 \\
Rosni, SE & PBB & 1.262 \\
\hline Farida Gamaruddin, S.Pi & Golkar & 842 \\
Baniu & Nasdem & 796 \\
Drs. La Ode Hadia, M.Si & Gerindra & 718 \\
M Yumardin H, S.KM., M.Kes & PDIP & 822 \\
Drs. H. Masri, M.Pd & PAN & 821 \\
Alianti, S.Pd & PKB & 806 \\
La Ode Yasin & Hanura & 895 \\
\hline
\end{tabular}

\section{Sumber: KPU Kota Baubau}

Jika melihat pelaksanaan Pemilihan Umum Legislatif Tahun 2019 kemarin, kinerja Badan Pangawas Pemilihan Umum Kota Baubau sudah dapat dikatakan efektif. Kefektifan tersebut dikarenakan kewenangan yang dimiliki oleh Bawaslu Kota Baubau, ketegasan dalam melakukan penindakan terhadap pihak-pihak yang melakukan pelanggaran.Dalam menyelesaikan pelanggaran-pelanggaran yang terjadi selama Pemilihan Umum Tahun 2019, Bawaslu Kota Baubau telah melaksanakan tugas sesuai dengan amanat Undang-Undang yang berlaku.

Akan tetapi meskipun pemilu legislatif telah berakhir, masih ada sejumlah pekerjaan rumah yang harus diselesaikan agar menjadi evaluasi untuk pemilu kedepannya, yaitu banyaknya pelanggaran yang masih mewarnai pesta demokrasi di Kota Baubau.Pelanggaran-pelanggaran yang terjadi selama pemilhan umum tidak dibiarkan begitusaja, Bawaslu Kota Baubau beserta jajarannya hadir sebagai lembaga yang bertugas mengawasi dan menindaklanjuti setiap pelanggaran yang terjadi. 
Eksistensi Bawaslu Kota Baubau diwujudkan dalam pengawasan yang dilakukan terhadap setiap tahapan Pemilihan. Di samping itu, Bawaslu Kota Baubau juga mempunyai eksistensi dalam menyelesaikan dugaan pelanggaran yang terjadi selama Pemilihan umum.

\section{Pengawasan Pemilu Legislatif di Kota Baubau}

Pemilu Legislatif Kota Baubau Tahun 2019 diwarnai dengan berbagai macam Mal Praktek Pemilu. Mal Praktek memiliki pengertian proses manipulasi yang terjadi pada setiap keseluruhan proses penyelenggaraan pemilu yang bertujuan untuk kepentingan perseorangan, kelompok atau partai politik dengan menggadaikan kepentingan umum (Ratnia Solihah, Arry Bainus dan Iding Rosyidin, 2018).Mal Praktek pemilu bergantung pada kualitas dari demokrasi suatu negara.Ketika peserta dan pelaksana berkoasi dalam mencurangi pemilihan maka akan melahirkan pemimpin-pemimpin yang tidak kredibel dan tidak berintegritas.

Berdasarkan laporan Bawaslu setidaknya telah mencatat 10 perkara yang terjadi selama tahapan Pemilu 2019 berlangsung di Kota Baubau.Satu diantaranya merupakan laporan dari masyarakat dan sembilan lainnya adalah hasil temuan Panwas (sultra.antaranews.com).

Laporan pengawasan tersebut harus memenuhi syarat $5 \mathrm{~W}$ (who, why, where, what, when) artinya mengetahui siapa yang melakukan, mengapa, dimana terjadinya, pelanggaran seperti apa dan kapan terjadinya, juga $1 \mathrm{H}$ (how) artinya bagaimana kronologis kejadiannya. Laporan tersebut kemudian akan diteliti dan ditelaah lagi oleh Bawaslu Kota Baubau, apakah sudah terpenuhi syarat-syarat sebagai delik aduan. Hal inilah yang kemudian menjadi salah satu parameter demokratis pemilu legislatif dilihat dari segi pengawasan.

Beberapa kasus di atas merupakan salah satu potret bagi integritas pemilu legislatif Kota Baubau dimana praktek tersebut masih saja berlangsung dan bisa jadi kasus di atas merupakan puncak dimana masih banyak terdapat mal praktek pemilu di Kota Baubau. Tentu akan menjadi pembahasan menarik ketika kita berfikir bagaimana mengawal agar proses pemilihan yang sudah baik saat ini tidak dinodai dengan kecurangan.

Salah satu aspek penting dalam mensukseskan pemilu legislatif Kota BauBau Tahun 2019 adalah pengawasan dan penanganan pelanggaran secara maksimal guna menjadikan pemilu tersebut menjadi pemilihan yang jujur dan adil sesuai dengan ketentuan undang-undang yang berlaku.

Bawaslu Kota Baubau berupaya mensosialisasikan berbagai regulasi terkait Pemilu kepada masyarakat dan meningkatkan peran aktif masyarakat dalam mengawasi pemilu, dengan harapan bahwa pelanggaran pemilu semakin berkurang karena adanya kesadaran dari masyarakat dan peserta pemilu untuk tidak melakukan pelanggaran (Suak,J.A, 2017).

Salah satu tantangan terkait pengawasan adalah untuk meningkatkan kemauan masyarakat untuk melaporkan setiap pelanggaran atau kecurangan yang ditemui. Hal ini tentu saja merupakan kerja keras dari Bawaslu Kota Baubau untuk mengadakan sosialisasi akan adanya salah satu kewajiban sebagai masyarakat untuk mengawasi setiap tahapan penyelenggaran pemilu legislatif, bukan hanya kewajiban untuk ikut 
berpartisipasi politik dalam hal ikut memilih saja. Dengan demikian, Bawaslu yang dipandang oleh beberapa pihak, sebagai lembaga pencari kesalahan diubah cara pandangnya sebagai lembaga yang proaktif melakukan pencegahan dini pelanggaran melalui sosialisasi, pendidikan pemilih tanpa melupakan keseriusan dan kesungguhan dalam menangani pelanggaran yang terjadi untuk memberi efek jera bagi para pelanggar-pelanggar.

Hal ini merupakan perkembangan yang positif, karena dengan adanya pelibatan masyarakat maka hasil pemilu pun akan lebih dipercaya oleh masyarakat. Sehingga mereka akan berlapang dada menerima penetapan hasil pemilu, baik dari segi partai politik, calon dan juga pemilih.

Selain pengawasan dari publik (masyarakat), partai politik selaku peserta pemilu harus menjadi komponen yang ikut mengawasi jalannya pemilu juga bukan hanya menjadi sebagai peserta saja, artinya mereka juga harus memiliki kesadaran untuk menjadi peserta pemilu yang berintegritas dimana tidak melakukan pelanggaran pemilu. Menjaga dan mengawasi kader-kadernya agar menjadi kader yang memiliki kesadaran politik bahwa mereka juga sebagai bagian dari masyarakat yang harus ikut serta dalam mengawal integritas proses dan hasil pemilu tersebut.

Partai politik juga harus menyadari fungsinya sebagai alat sosialisasi politik yang harusnya ikut berperan serta untuk membangun kepercayaan terciptanya pemilu yang jujur di masyarakat sebagai tanggung jawab politiknya terhadap masyarakat.Selain partai-partai politik, Komisi Pemilihan Umum (KPU) sebagai lembaga penyelenggara Pemilu ikut berperan serta dalam pengawasan tahapan penyelenggaraan pemilu.Hal ini diakomodir dengan diadakannya sosialisasi terhadap semua ketentuan dalam setiap tahapan penyelenggaran pemilu.

Bawaslu dalam mengawasi jalannya pemilu legislatif seharusnya independen dan tidak memihak (imparsial) pada salah satu calon atau partai politik peserta pemilu, sehingga pemilihan bisa dilaksanakan secara fair dan jujur tanpa adanya diskriminasi. Seluruh calon dan partai politik peserta pemilu diperlakukan secara adil dan sama dari segi pengawasan agar pemilu legislatif bisa berjalan sesuai dengan kehendak yang diharapkan.

\section{KESIMPULAN}

Berdasarkan pembahasan di atas, dapat disimpulkan Implementasi Badan Pengawas Pemilihan Umum Kota Baubau Dalam Pengawasan Pemilihan Umum Legislatif telah efektif dapat dilihat Bawaslu Kota Baubau bersikap tidak diskriminatif dalam menjalankan tugas dan wewenangnya; Bawaslu Kota Baubau melakukan pembinaan dan pengawasan terhadap pelaksanaan tugas pengawas pemilu pada tingkat bawahnya; Bawaslu Kota Baubau menerima dan menindaklanjuti setiap laporan yang berkaitan dengan dugaan adanya pelanggaran terhadap pelaksanaan peraturan perundang-undangan mengenai pemilu; Bawaslu Kota Baubau telah transparan dalam menyampaikan setiap hasil pengawasan kepada Bawaslu provinsi sesuai dengan tahapan pemilu secara periodi dan/atau berdasarkan kebutuhan; dan Bawaslu Kota Baubau telah meyampaikan setiap temuan dan laporan kepada Bawaslu Provinsi berkaitan dengan adanya dugaan pelanggaran yang terjadi dalam pemilihan umum Kota Baubau. 


\section{UCAPAN TERIMAKASIH}

Terima kasih kepada seluruh pihak yang membantu dan terlibat dalam penelitian initerkhusus kepada KPU Kota Baubau dan Bawaslu Kota Baubau yang telah memberikan ruang dan kesempatan kepada kami untuk melakukan penelitian.Penulis juga mengucapkan terima kasih kepada rekan-rekan penulis di Program Studi IImu Pemerintahan Fakultas IImu Sosial dan IImu Politik, Universitas Muhammadiyah Buton yang telah menjadi teman diskusi selamapenulisan naskah ini.

\section{DAFTAR PUSTAKA}

Anggoro, T., \& Mulyatin, T. C. (2020). KIPRAH POLITIK PURNAWIRAWAN ( Studi Tentang Strategi Politik Pemenangan Calon Legislatif Purnawirawan TNI Pada Pemilu Legislatif di Kota Banjar Tahun 2019 ). 15(02), 240-252.

Bloor, M. (1997). Techniques of Validation in Qualitative Research: A Critical Commentary. London: Sage.

Creswell, John W. (2010). Research Design: Pendekatan Kualitatif, Kuantitaif, dan Mixed. Yogyakarta: Pustaka Pelajar, Terjemahan.

Febriadi, H. (2018). Al'Adl, Volume X Nomor 1, Januari 2018. ISSN 1979-4940/ISSN-E 2477-0124. IMPLEMENTASI UU NO 7 TAHUN 2017 TERHADAP KEDUDUKAN DAN KINERJA PANITIA PENGAWAS PEMILU KABUPATEN HULU SUNGAI UTARA, $x(1), 1689-1699$. https://doi.org/10.1017/CBO9781107415324.004

Kartini, D. S. (2017). Demokrasi dan Pengawas Pemilu. Journal of Governance, 2(2), 146-162. https://doi.org/10.31506/jog.v2i2.2671

Ratnia Solihah, Arry Bainus dan Iding Rosyidin. (2018). Jurnal Wacana Politik - ISSN 2502 - 9185 : PENTINGNYA PENGAWASAN PARTISIPATIF DALAM MENGAWAL PEMILIHAN UMUM YANG DEMOKRATIS, 3(1), 14-28.

Solihah, R. (2018). Peluang dan tantangan pemilu serentak 2019 dalam perspektif politik. Jurnal IImiah IImu Pemerintahan, 3(1), 73. https://doi.org/10.14710/jiip.v3i1.3234

Studi, P., Di, K., \& Purwakarta, K. (2020). Peran Aktor Dalam Proses Pembentukan Dinasti. 3(1), 26-48. https://doi.org/10.23969/paradigmapolistaat.v3i1.2931

Suak,J.A.(2017). Pengawasan Partisipatif danPemantauan Pemilu. Diakses pada http://manadopost.online.com/read/2017/07/28/Pengawasan-Partisipatif-danPemantauan-Pemilu/25212. 28 Februari2018.

Syarbaini, Syahrial, Dkk. 2002. Sosiologi dan Politik. Jakarta : Ghalia Indonesia.

Surbakti, Ramlan; Supriyanto, Didik; Santoso, T. (2008). Perekayasaan Sistem Pemilihan Umum: untuk Pembangunan tata Politik Demokratis.

Undang-Undang No 7 Tahun 2017 tentang Pemilihan Umum

https://kumparan.com/kendarinesia/bawaslu-baubau-tangani-10-pelanggaran-selamatahapan-pemilu-1554129982491658208/full

https://sultra.antaranews.com/berita/303951/di-baubau-bawaslu-rekomendasikan-13tps-lakukan-psu

https://sultra.antaranews.com/berita/292706/kpu-baubau-terbagi-tiga-dapil 